\title{
Effects of Crush Process on Methane Conversion Efficiency in Thermophilic Anaerobic Digestion with Coffee Grounds
}

\author{
Yugo TAKABE, Kohei YAMASE, Kohsuke WATANABE, Yasunari KUSUDA, Tadao \\ MIZUNO, Fumitake NISHIMURA \\ Department of Environmental Engineering, Kyoto University, Kyoto-Daigaku-Katsura, \\ Nishikyo-ku, Kyoto 615-8540, Japan
}

\begin{abstract}
Effects of a crush process on methane conversion efficiency in thermophilic anaerobic digestion with coffee grounds were evaluated. The crush process was performed with a blender $(10,000$ $\mathrm{rpm}$ ). In batch experiments, solubilization rates for crushed coffee grounds (representative particle size: $320 \mu \mathrm{m}$ ) were greater than $8.10 \%$ at $55^{\circ} \mathrm{C}$ for $24 \mathrm{~h}$, and the rate for uncrushed grounds $(>1,000 \mu \mathrm{m})$ was $5.00 \%$ under the same conditions. In a batch experiment, methane conversion efficiency for crushed grounds (45.4\%) was higher than that for uncrushed grounds $(27.7 \%)$ in the thermophilic anaerobic digestion process $(120 \mathrm{~h})$. The contribution of acetic acid to the conversion efficiency was suggested. Continuous experiments (solubilization and thermophilic anaerobic digestion) were conducted with loading rates of 5 and $6.5 \mathrm{~kg}$ $\mathrm{COD} / \mathrm{m}^{3} /$ day. The experiments also showed average efficiencies for the crushed samples $(41.1 \%$ and $39.3 \%, 5$ and $6.5 \mathrm{~kg} \mathrm{COD} / \mathrm{m}^{3} /$ day, respectively) were higher than uncrushed samples $(33.4 \%$ and $32.4 \%$ ). Moreover, the crushing process improved the total solid decomposition. Based on these results, it was found that anaerobic digestion using a crush process is effective, especially for coffee grounds with a representative particle size of $320 \mu \mathrm{m}$.
\end{abstract}

Keywords: coffee grounds, crush process, solubilization process, thermophilic anaerobic digestion

\section{INTRODUCTION}

The development of a low carbon society has been proposed to resolve global environmental problems, such as global warming and energy source depletion, and the demand for renewable energy has increased. Anaerobic digestion produces methane from biomass materials, including kitchen garbage and sewage sludge, and has some advantages, such as the reduction of fossil fuel consumption and waste volumes. Compared with psychrophilic and mesophilic anaerobic digestion, thermophilic anaerobic digestion has advantages in methane production, treatment time and loading rates (Cooney and Wise, 1975; Noike, 2009).

A massive number of people in the world drink coffee, and its consumption has increased in Japan. The annual production of coffee grounds has reached approximately 500 thousand tonnes (wet base) (All Japan Coffee Association, 2012). Incineration is not a good disposal method because of the high moisture content of coffee grounds, and the development of effective recycling techniques is required. It is likely that anaerobic digestion is one solution.

Lane (1983) conducted the mesophilic anaerobic digestion of coffee grounds and accomplished $0.54 \mathrm{~m}^{3} / \mathrm{kg}$ of methane gas generation $(56 \%-63 \%$ methane

Address correspondence to Yugo Takabe, Recycling Research Team, Materials and Resources Research Group, Public Works Research Institute, Email: yu-takabe@pwri.go.jp

Received May 10, 2013, Accepted November 11, 2013. 
concentration) with a loading rate of $3 \mathrm{~kg}$ coffee grounds $/ \mathrm{m}^{3} /$ day. Dinsdale et al. (1996) performed the mesophilic anaerobic digestion of coffee waste containing coffee grounds (loading rate: $1.3 \mathrm{~kg} \mathrm{COD} / \mathrm{m}^{3} /$ day and HRT: 25 days), and $0.34 \mathrm{~L} / \mathrm{L} /$ day of gas generation and $60 \%$ removal of COD and VS were obtained. Daoming and Forster (1993) conducted a study in which they used upflow sludge blanket reactors for the thermophilic digestion of coffee grounds. By adding calcium ions, a COD decomposition rate of over $75 \%$ was accomplished with a loading rate of $4 \mathrm{~kg}$ $\mathrm{COD} / \mathrm{m}^{3} /$ day and an HRT of 12 days.

Solubilization and hydrolysis, which are followed by the anaerobic digestion process, are rate-determining processes when organic solids are digested (Noike, 2009). In addition, a crush process for solids as pretreatment is often performed for effective digestion because it promotes solubilization (Kamachi et al., 2010). Therefore, it is expected that the addition of a solubilization process, e.g. a crush process, would be effective for the digestion of coffee grounds. However, this particular idea has received little attention.

In this study, the effects of a crush process on solubilization and thermophilic anaerobic digestion processes with coffee grounds were analysed by batch experiments and continuous treatment experiments (crush, solubilization and thermophilic anaerobic digestion processes) to examine the effectiveness of a crush process for the anaerobic digestion of coffee grounds.

\section{MATERIALS AND METHODS}

\section{Batch experiments}

Batch experiments for the solubilization process and anaerobic digestion after solubilization were conducted to obtain basic information about the influence of the crush process (Fig. 1 (a), (b) and (c)).

The crush process was performed with a blender (TM835, Tescom, Japan: 10,000 rpm). The distribution of particle size by each crush period, which is shown in Fig. 2, was measured with a SALD-2200 laser diffraction particle size analyzer (Shimadzu, Japan). The particle size of the original coffee grounds was mostly larger than $1,000 \mu \mathrm{m}$. The distribution of particle size became smaller with the extension of the crush period, and the representative particle size of the coffee grounds decreased from $530 \mu \mathrm{m}$ to $160 \mu \mathrm{m}$ with a $0.5-5$ min crush process. The size did not change significantly when crushing continued for more than 5 min. Therefore, a crush period of 5 min was applied in this study.

Before the solubilization process, coffee grounds were crushed. Five cases were examined (Case 1-1: 0 min crushing (representative particle size: $>1,000 \mu \mathrm{m}$ ), 1-2: 0.5 $\min (530 \mu \mathrm{m}), 1-3: 1 \min (450 \mu \mathrm{m}), 1-4: 2 \min (320 \mu \mathrm{m})$ and 1-5: $5 \min (160 \mu \mathrm{m}))$. Each coffee sample was solubilized for $24 \mathrm{~h}$ with $10 \mathrm{~mL}$ of $2 \mathrm{~N} \mathrm{KOH}$ for the adjustment of $\mathrm{pH}$ and the enhancement of the chemical solubilization and ion-exchanged water (IEW) (Fig. 1 (a)). Before the experiment, the effects of solubilization temperature on methane conversion efficiency were investigated by batch experiments. It was determined that the changes of solubilization temperature from $55^{\circ} \mathrm{C}$ to $80^{\circ} \mathrm{C}$ had little 
influence on methane conversion efficiency of coffee grounds; therefore, a solubilization process under $55^{\circ} \mathrm{C}$ was applied in this study.

During the batch experiments, $40 \mathrm{~mL}$ of the solubilized sample was collected at each sampling, and the samples were filtered with GF/B filters (Whatman, USA). Soluble COD (S-COD) and $\mathrm{pH}$ were measured, and the solubilization rate was calculated by the following formula:

Solubilization rate $(\%)=\left(S-C O D_{t}-S-C O D_{\text {inf }}\right) /\left(T-C O D_{\text {inf }}-S-C O D_{\text {inf }}\right) \times 100$

where $S-C O D_{t}$ is the S-COD of coffee grounds at time $\mathrm{t}(\mathrm{mg} \mathrm{COD} / \mathrm{L})$, and $S-C O D_{\text {inf }}$ and $T-C O D_{\text {inf }}$ are S-COD and total COD (T-COD) of loaded coffee grounds (mg COD/L), respectively. $T-C O D_{i n f}$ was calculated by theoretical oxygen demand $\left(0.55 \mathrm{~g} \mathrm{O}_{2} / \mathrm{g}\right.$-wet $)$ based on water content and the average composition $\left(\mathrm{C}_{4.42} \mathrm{H}_{7.87} \mathrm{O}_{2.25} \mathrm{~N}_{0.14}\right)$ obtained by five measurements. The measured COD value of coffee grounds was $0.55 \pm 0.099 \mathrm{~g}$ $\mathrm{O}_{2}$ /g-wet (average \pm standard deviation), which was obtained through eight measurements, and this value is the same as the theoretical value. In addition, it was defined that the solubilization rate included solubilization by the crush process.

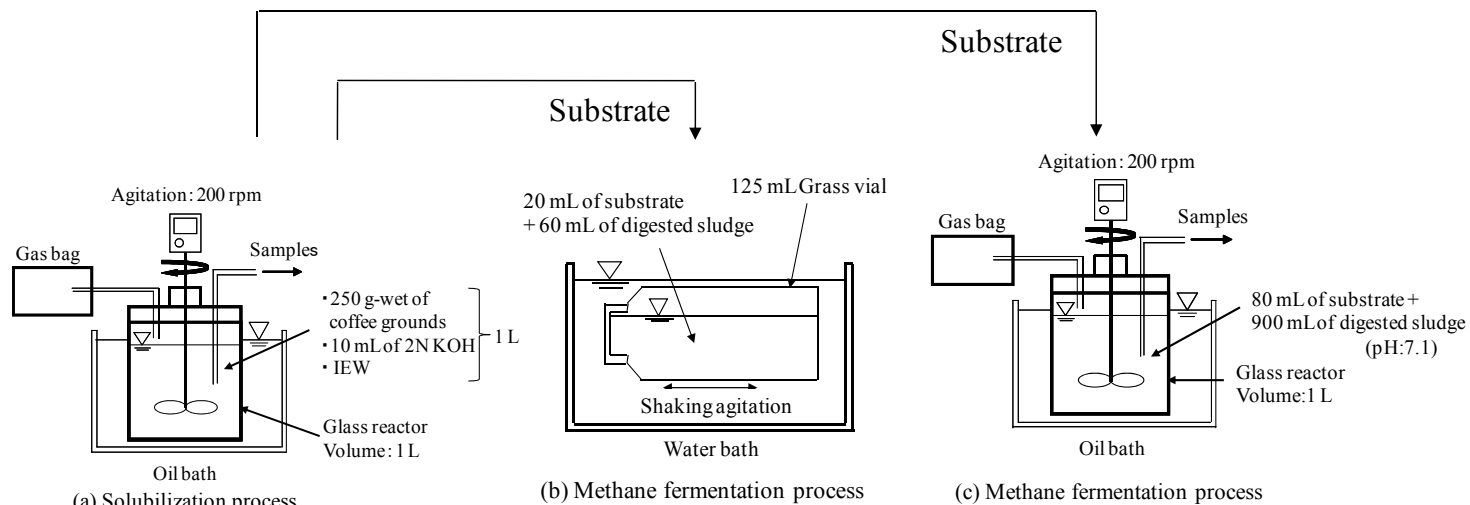

Fig. 1 - Schematic diagrams of batch experiments.

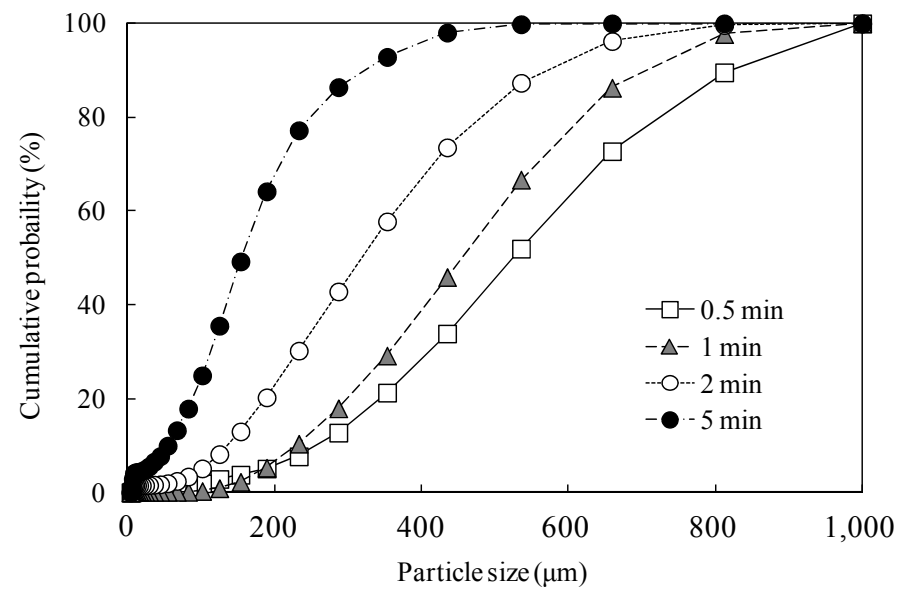

Fig. 2 - Distribution of the particle size of coffee grounds by each crush period. 
Other experiments for anaerobic digestion were subsequently conducted (Fig. 1 (b)) with each solubilized sample described above (Cases 1-1 to 1-5), and the digested sludge $(\mathrm{pH}=7.31)$ from the anaerobic digestion experiments was used as the microorganism for digestion. The $\mathrm{pH}$ values of the solubilized samples of Cases 1-1 to 1-5 were 7.21, 7.18, 7.13, 7.11 and 7.07, respectively. The solubilized coffee grounds were diluted by IEW, and $\mathrm{NH}_{4} \mathrm{HCO}_{3}$ and some nutrients were added to the diluted coffee grounds (substrate). The substrate and digested sludge were mixed and anaerobic digestion was performed for $120 \mathrm{~h}$. The temperature for the process was set at $55^{\circ} \mathrm{C}$ (thermophilic) (Lee et al., 2008). A vial with only the sludge was prepared as a control. The volumes of the generated biogas were measured, and the composition was analysed by gas chromatography equipped with thermal conductivity detector (GC-TCD) (GC-14B, Shimadzu, Japan). Methane conversion efficiency was calculated by the following formula:

Methane conversion efficiency $(\%)=C O D_{C H 4} / T-C O D_{i n f} \times 100$

where $\mathrm{COD}_{\mathrm{CH} 4}$ is the $\mathrm{COD}$ equivalent value of generated methane (mg $\left.\mathrm{COD} / \mathrm{L}\right)$. After the experiments, the mixed sludge was collected and filtered. The $\mathrm{pH}, \mathrm{S}-\mathrm{COD}$, volatile fatty acids (VFA), including acetic, lactic, propionic, $n$-butyric, $i s o$-valeric and $n$-valeric acids were measured by HPLC (CDD-10Avp, Shimadzu, Japan).

Another batch experiment for the anaerobic digestion process was conducted to examine the changes of VFA concentrations during the process. The coffee grounds samples from $0 \mathrm{~min}(2-1)$ to $2 \mathrm{~min}(2-2)$ crush processes were solubilized at $55^{\circ} \mathrm{C}$ for 24 h. Each solubilized sample was diluted twice by IEW, and $\mathrm{NH}_{4} \mathrm{HCO}_{3}$ and some nutrients were added to the diluted samples (substrate). The substrate and digested sludge were mixed and anaerobic digestion was performed at $55^{\circ} \mathrm{C}$ and $\mathrm{pH} 7.1$ for $120 \mathrm{~h}$ (Fig. 1 (c)). Six millilitres of the samples were collected at each sampling, and these samples were then diluted and filtered. The volume and the composition of the generated gas and VFA concentrations were measured.

\section{Continuous experiments}

The schematic diagrams of the continuous experiments are shown in Fig. 3. The system consists of a crush process, a solubilization process and an anaerobic digestion process with a submerged membrane. Three reactors (Reactor A, B and C) were set, and the only difference among them was the crush period. Coffee grounds were crushed (Reactor A: $0 \mathrm{~min}, \mathrm{~B}: 1 \mathrm{~min}$ and $\mathrm{C}: 2 \mathrm{~min}$ ) with treated effluent from the anaerobic digestion process to stabilize $\mathrm{pH}$. The crushed coffee grounds were solubilized with $2 \mathrm{~N}$ $\mathrm{KOH}$ and the treated effluent at $55^{\circ} \mathrm{C}$ for $24 \mathrm{~h}$. The solubilized sample was recovered and diluted twice to adjust the total solid (TS) concentrations. Some nutrients and $\mathrm{NH}_{4} \mathrm{HCO}_{3}$ were added to the sample and were stored at room temperature. The amount of $\mathrm{NH}_{4} \mathrm{HCO}_{3}$ was adjusted depending on the $\mathrm{pH}$ in the anaerobic digestion process. The stored substrate was fed to the anaerobic digestion process eight times a day. 


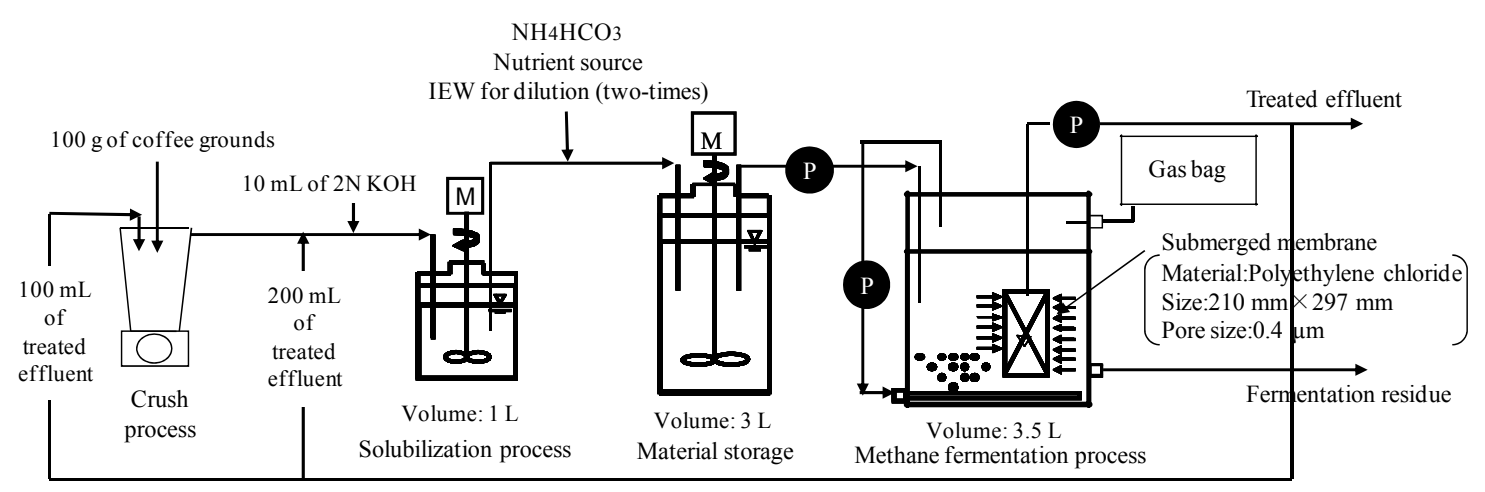

Fig. 3 - Schematic diagrams of continuous experiments.

The anaerobic digestion process with submerged membranes was performed at $55^{\circ} \mathrm{C}$. The membrane bioreactor (MBR) system was used to maintain a high concentration of microbes and extract fermentation inhibitors. The generated gas was circulated in the system to agitate the mixed liquid and wash the surface of the membrane.

Seed sludge in the experiment was taken from a continuous experiment in which the substrate was also coffee grounds, and the loading rate was $6.5 \mathrm{~kg} \mathrm{COD} / \mathrm{m}^{3} /$ day.

At the beginning, the loading rate was $5 \mathrm{~kg} \mathrm{COD} / \mathrm{m}^{3} /$ day with HRT of 13.9 days, and increased to $6.5 \mathrm{~kg} \mathrm{COD} / \mathrm{m}^{3} /$ day (9.83 days) between day 43 and day 70 . The loading rates were adjusted by an increase of the inlet flow. Irrespective of the increase, the solid retention time was constant ( 81.9 days) because of the membrane and the constant amount of sludge removal. The concentration of TS was $38.7 \mathrm{~g} / \mathrm{L}$ in the inflow.

Methane producers (Methanosarcina thermophila and Methanoculleus thermophilus) in the fermentation residue, VFA, $\mathrm{pH}$ and TS were measured. The gas volume and composition were also measured.

\section{Analytical methods}

A D-52 $\mathrm{pH}$ meter (Horiba, Japan) was used to measure $\mathrm{pH}$, and standard COD (potassium dichromate method) and TS methods were employed (APHA-AWWA-WEF (2005)).

A 16S rRNA gene was extracted using a DNeasy Blood \& Tissue Kit (Qiagen, Hilden, Germany). For real-time PCR (polymerase chain reaction), LightCycler 1.2 (Roche, Mannheim, Germany) was used to quantify the target microbes. A primer set of MSAT942F (5'-caa tat gta ggc cag gct aaa ga-3') and MSAT1246R (5'-cta cgg atg ggt ttg gga ga-3'), and MCUT144F (5'-atg ctg gaa tgc ceg gta tc-3') and MCUT387R (5'-acc cag aca gcc tgc atg tac-3') were used for Methanosarcina thermophila and Methanoculleus thermophilus, respectively. A procedure outlined in a previous study was followed (Hidaka et al., 2010). 


\section{RESULTS AND DISCUSSION}

\section{Batch experiments}

The solubilization rate was $2.2 \%, 2.5 \%, 3.4 \%$ and $4.2 \%$ for the $0.5 \mathrm{~min}, 1 \mathrm{~min}, 2 \mathrm{~min}$ and 5 min crush processes, respectively. Figure 4 shows the solubilization rate for Cases 1-1 to $1-5$, including solubilization by the crush process, which increased with the extension of the crush period. The solubilization rate and $\mathrm{pH}$ in Cases 1-1 to 1-5 at $24 \mathrm{~h}$ were $5.00 \%$ and $6.01,5.63 \%$ and $6.09,7.03 \%$ and $5.90,8.10 \%$ and 6.04 and $10.2 \%$ and 6.00 , respectively. Little difference in $\mathrm{pH}$ was observed among the experiments.

It has been reported that combining the hyperthermophilic solubilization process and waste heat from power generation systems with biogas and energy from increased biogas could cover the heat energy to maintain the process (Tsubota et al., 2008).

Therefore, considering the cost, it is reasonable to conduct solubilization processes at $55^{\circ} \mathrm{C}$.

Methane production for Cases 1-1 to $1-5$ is shown in Fig. 5. In a previous study, Watanabe et al. (2012) conducted a similar batch experiment for anaerobic digestion with solubilized coffee grounds at $80^{\circ} \mathrm{C}$ using five experimental systems. The ranking of methane production among the systems did not change between a period in which production increased linearly and the approximate end of production. Therefore, in this study, comparisons of production among these cases were conducted with a linearly increasing period.

The production increased with the extension of the crush period for Cases 1-1 to 1-4, and methane conversion efficiencies at $120 \mathrm{~h}$ were $27.7 \%, 35.9 \%, 39.1 \%$ and $45.4 \%$, respectively. However, the efficiency was $39.7 \%$ for Case $1-5$ at $120 \mathrm{~h}$, which is lower than that of Case 1-4. Therefore, it was determined that anaerobic digestion with a crush process of $2 \mathrm{~min}$ (representative particle size: $320 \mu \mathrm{m}$ ) was the most effective.

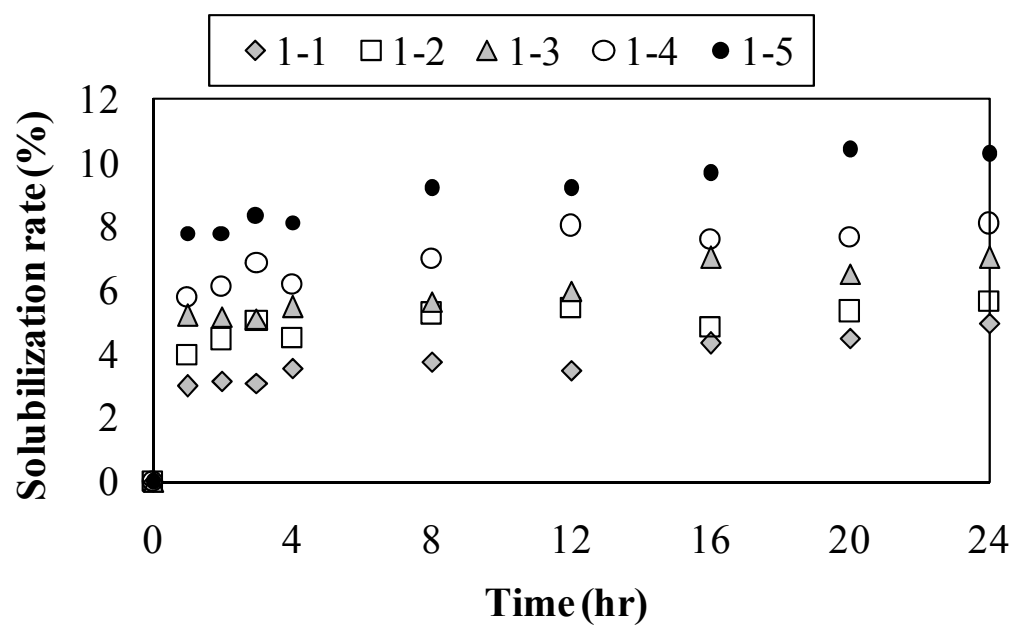

Fig. 4 - Solubilization rates. 


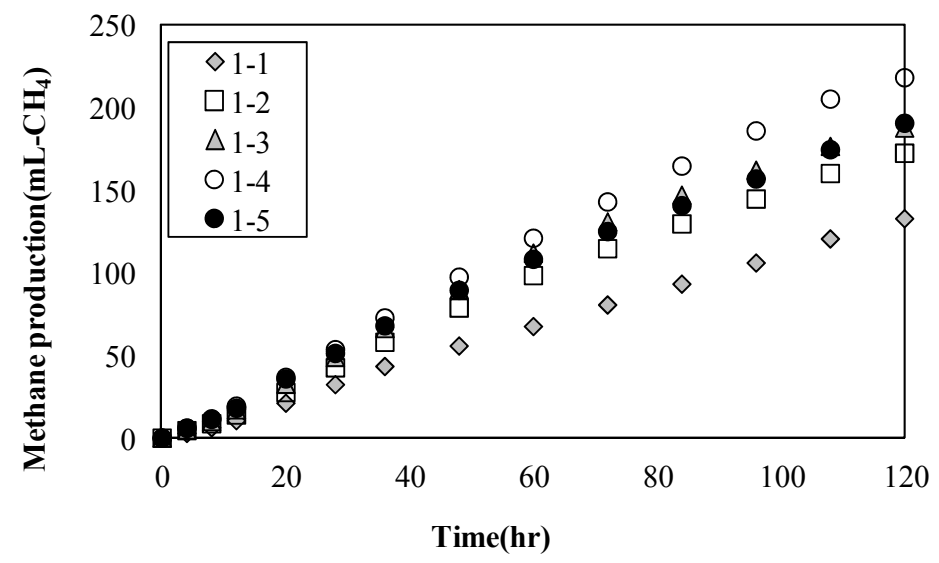

Fig. 5 - Methane production.

By comparing the solubilization rates shown in Fig. 4, it can be understood that methane conversion efficiency was much higher. Therefore, it is likely that the solubilization progressed in the anaerobic digestion process. In addition, a decrease of particle size and an increase of surface area by the crush process consequently resulted in the enhancement of solubilization and methane fermentation in the anaerobic digestion process.

Table 1 shows $\mathrm{pH}$ and VFA concentrations at $24 \mathrm{~h}$. The experiments showed similar $\mathrm{pH}$. The concentrations of propionic acid increased slightly with the extension of the crush period. In addition, the accumulation of acetic acid was observed in Case 1-5. It is known that VFAs greater than $1,000-2,000 \mathrm{mg} / \mathrm{L}$ can inhibit anaerobic digestion. Therefore, it is possible that the accumulation of VFAs in Case 1-5 inhibited methane production.

Figure 6 shows the production of methane for Cases 2-1 and 2-2. It was found that the production and methane conversion efficiency in Case 2-2 (methane conversion efficiency: $37.6 \%$ at $120 \mathrm{~h}$ ) was higher than that of Case $2-1(28.1 \%$ at $120 \mathrm{~h})$. It was observed that the differences that occurred up to approximately $72 \mathrm{~h}$ were the primary contributors to the total differences between the two experiments.

Figure 7 shows the VFA concentrations for Cases 2-1 and 2-2. Acetic acid was detected by $60 \mathrm{~h}$ in Case $2-1$ and $84 \mathrm{~h}$ in Case 2-2, and was higher in Case 2-2 (220 mg COD/L in $2-1$ and $590 \mathrm{mg} \mathrm{COD} / \mathrm{L}$ in $2-2$ at $36 \mathrm{~h}$ ). In addition, the differences in methane conversion efficiency between the experiments occurred primarily in the first $72 \mathrm{~h}$ described above. Therefore, it can be suggested that the enhancement of acetic acid generation by the crush process contributed to the development of methane conversion efficiency.

After $72 \mathrm{~h}$, acetic acid was not detected in either experiment. It is well known that in the anaerobic digestion process, $70 \%$ of generated methane is derived from acetic acid (Shigematsu et al., 2009). Methane generation occurred continuously after this period. Therefore, the generated acetic acid was converted to methane rapidly and was not detected at this point. 
Table $1-\mathrm{pH}$ and VFA concentrations.

\begin{tabular}{|c|c|c|c|c|c|}
\hline Parameter & $1-1$ & $1-2$ & $1-3$ & $1-4$ & $1-5$ \\
\hline $\mathrm{pH}(-)$ & 7.14 & 7.15 & 7.16 & 7.13 & 7.02 \\
\hline Acetic acid (mgCOD/L) & n.d. & n.d. & n.d. & n.d. & 740 \\
\hline Propionic acid (mgCOD/L) & n.d. & 250 & 610 & 610 & 660 \\
\hline Lactic acid (mgCOD/L) & n.d. & n.d. & n.d. & n.d. & n.d. \\
\hline
\end{tabular}

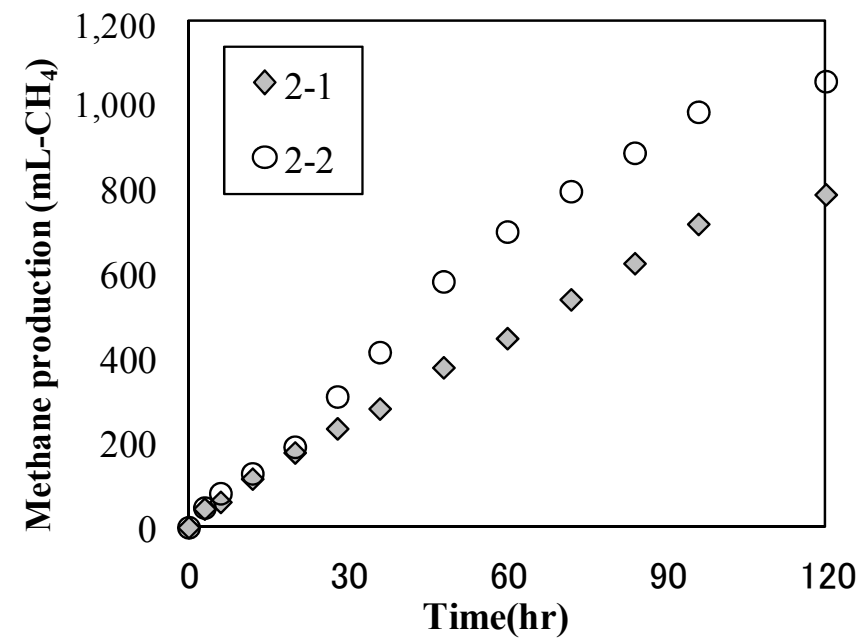

Fig. 6 - Methane production (2-1, 2-2).
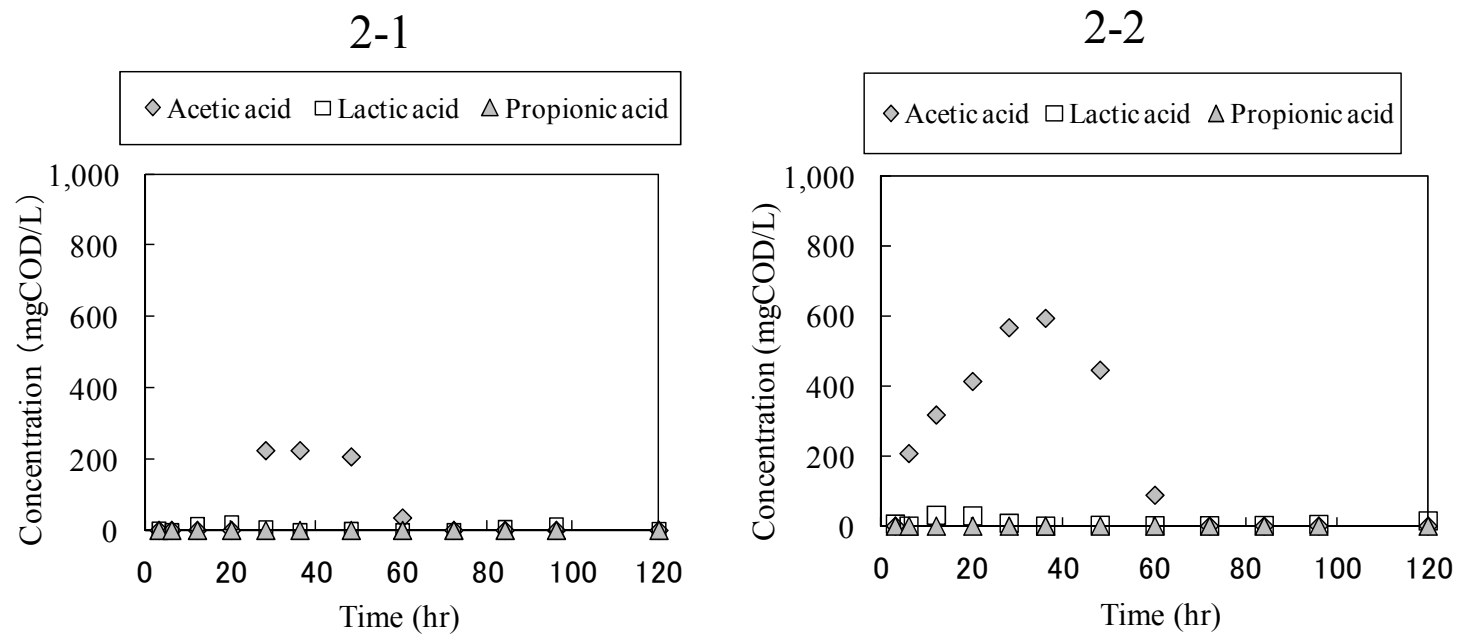

Fig. 7 - VFA concentrations (2-1, 2-2).

\section{Continuous experiments}

Average $\mathrm{pH}$ in Reactors $\mathrm{A}, \mathrm{B}$ and $\mathrm{C}$ was $7.40,7.38$ and 7.34 at a loading rate of $5 \mathrm{~kg}$ $\mathrm{COD} / \mathrm{m}^{3} /$ day and $7.28,7.27$ and 7.25 at a loading rate of $6.5 \mathrm{~kg} \mathrm{COD} / \mathrm{m}^{3} /$ day, respectively. During the operation, $\mathrm{pH}$ was adjusted in each reactor.

Methane conversion efficiency (Fig. 8) was calculated by the following formula: 
Methane conversion efficiency $(\%)=C O D_{C H 4(t)} / T-C O D_{\text {inf }(t)} \times 100$

where $T-C O D_{\inf (t)}$ is the loading rate of the substrate at day t. Methane conversion efficiency in each reactor at a loading rate of $5 \mathrm{~kg} \mathrm{COD} / \mathrm{m}^{3} /$ day seemed to be stable from day 20 to day 42, and average efficiencies in each reactor during the period were $33.4 \%, 38.4 \%$ and $41.1 \%$, respectively. Immediately after the loading rate was increased to $6.5 \mathrm{~kg} \mathrm{COD} / \mathrm{m}^{3} /$ day, the efficiency in each reactor decreased; however, it recovered quickly. Average efficiencies in each reactor were $32.4 \%, 33.6 \%$ and $39.3 \%$, respectively, from day 43 to day 68 , and the efficiencies were similar to those with a loading rate of $5 \mathrm{~kg} \mathrm{COD} / \mathrm{m}^{3} /$ day. Based on the results, the crush process enhanced methane conversion efficiencies of coffee grounds in the continuous experiments with loading rates of 5 and $6.5 \mathrm{~kg} \mathrm{COD} / \mathrm{m}^{3} /$ day for 70 days. Cost evaluation for the application of the process proposed in this study including the crush process will be considered in future work.

Figure 9 shows the VFA concentrations in Reactor C. Except for the detection of acetic acid in the early stage, no accumulation of VFA was observed in the period with a loading rate of $5 \mathrm{~kg} \mathrm{COD} / \mathrm{m}^{3} /$ day. However, acetic acid was detected in maximum concentrations of $1,200 \mathrm{mg} \mathrm{COD} / \mathrm{L}$, and the concentrations of propionic acid of approximately $600 \mathrm{mg} \mathrm{COD} / \mathrm{L}$ were observed in the latter half of the period at a load rate of $6.5 \mathrm{~kg} \mathrm{COD} / \mathrm{m}^{3} /$ day. This indicates that methane conversion from acids was a rate-determining process, irrespective of the successful generation of acids.

Several studies have reported the inhibition of methane production with coffee grounds for long-term operation. For example, Lane (1983) conducted the continuous thermophilic anaerobic digestion of coffee grounds with supplemental nitrogen. Initial methane production was $1.70 \mathrm{~L}-\mathrm{CH}_{4} / \mathrm{L} /$ day; however, the production decreased to 0.45 $\mathrm{L}-\mathrm{CH}_{4} / \mathrm{L} /$ day after 80 days. Ike et al. (2010) operated continuous thermophilic anaerobic digestion with coffee grounds as the main food waste. The inhibition of the production was observed after 110 days. In addition, Lane (1983) suggested that the decline of methane production could be because of inhibitory compounds in coffee grounds. However, these compounds were probably not accumulated to a level that would inhibit methane production.

As described above, VFAs at concentrations greater than $1,000-2,000 \mathrm{mg} / \mathrm{L}$ can inhibit anaerobic digestion and the decomposition of propionic acid is a rate-determining process in anaerobic digestion. Therefore, the inhibition of methane production was not observed in this study. Meanwhile, the process operation with 6.5 $\mathrm{kg} \mathrm{COD} / \mathrm{m}^{3} /$ day specifically should be performed carefully observing the acid accumulation. Similar results were obtained in Reactors A and B. 


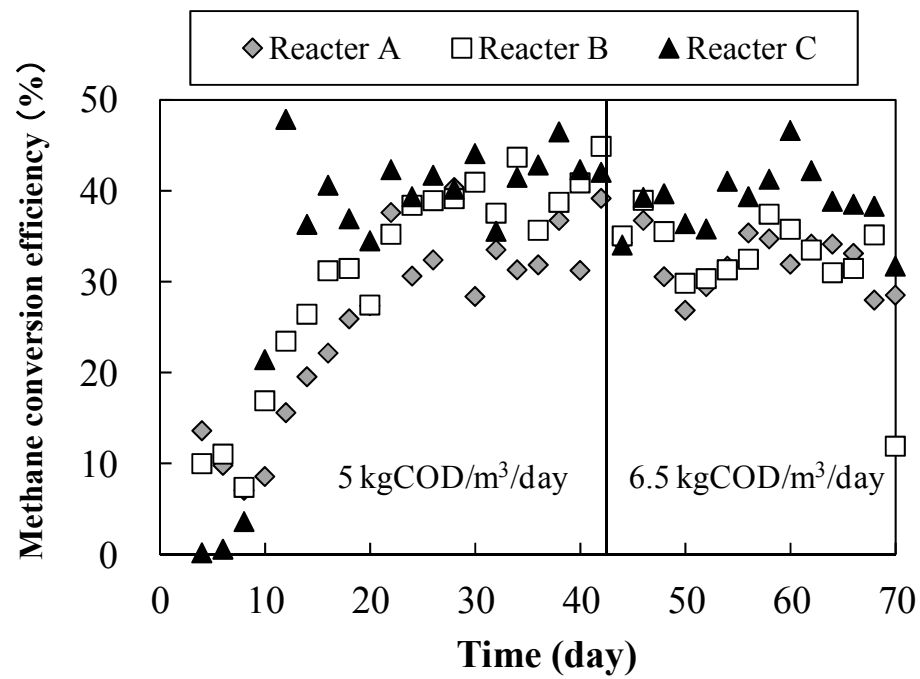

Fig. 8 - Methane conversion efficiency.

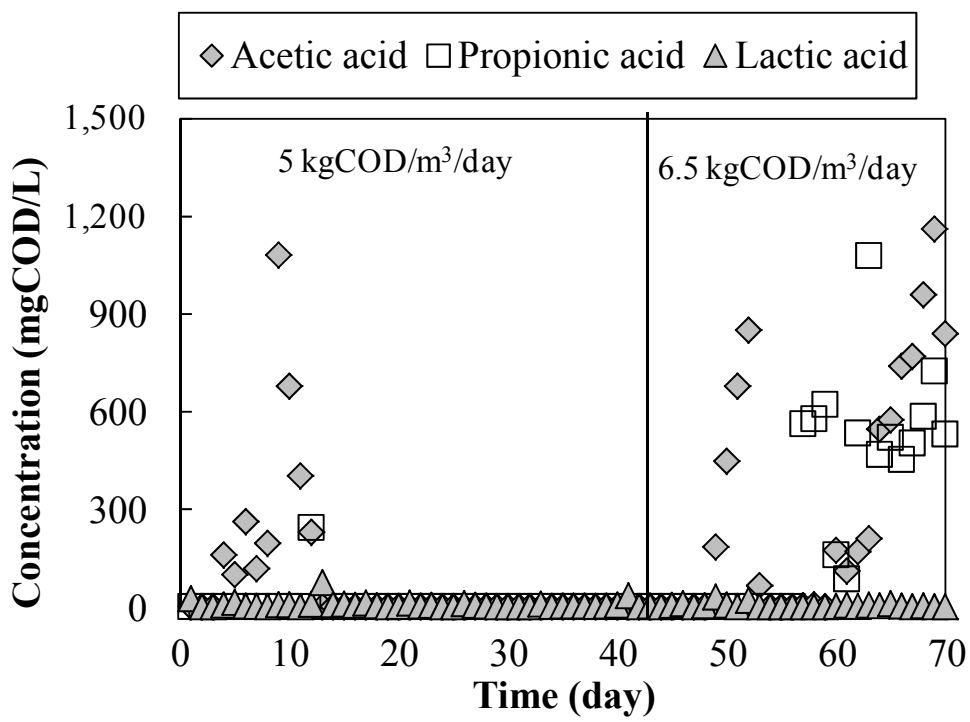

Fig. 9 - VFA concentrations in Reactor C.

\section{TS decomposition rate}

The TS decomposition rate in the anaerobic digestion process was calculated using the theoretically accumulated TS concentrations, which were calculated using Equation (4). The calculation was based on the following assumptions: 1) biological decomposition did not occur, 2) no solid existed in the treated effluent and 3) treated effluent was extracted first followed by the extraction of fermentation residues, and then the substrate was loaded. The equation is written as

$$
C_{\text {theo }(t)}=\frac{C_{\text {theo }(t-1)} \times V_{R}\left(1-\frac{V_{\text {out }_{2}}}{V_{R}-V_{\text {out }}}\right)+C_{\text {in }} \times V_{\text {in }}}{V_{R}}
$$


where $C_{\text {theo }(t)}$ is the theoretical TS concentration in the process at day t, $C_{\text {in }}$ is the TS concentration in the loaded substrate, $V_{\text {in }}$ is the volume of the substrate loaded in one day, $V_{R}$ is the volume of the mixed liquid in the process, $V_{\text {out } 1}$ is the volume of the extracted treated effluent in one day and $V_{\text {out } 2}$ is the volume of the extracted fermentation residue in one day. Then, the TS decomposition rate can be calculated by the following formula:

$T S_{\text {dec }(t)}=\left(C_{\text {theo }(t)}-C_{o b(t)}\right) / C_{\text {theo }(t)} \times 100$

where $T S_{\operatorname{dec}(t)}$ is the TS decomposition rate at day $\mathrm{t}$ and $C_{o b(t)}$ is the observed TS concentration in the process at day t. Figure 10 shows the TS decomposition rate in each reactor. The rate increased with time and reached approximately $65 \%$ in each reactor. The rate in Reactor A was lower than in the other reactors from day 20 to day 45. Therefore, it was concluded that the crush process also has an advantage in the decomposition of TS.

Figure 11 shows the mass of Methanosarcina thermophila and Methanoculleus thermophilus. They increased relative to the loading rate and the increase would contribute to the augmentation of generated methane. Cheon (2006) has suggested that the concentration of Methanosarcina thermophila required for anaerobic digestion is 9 $\times 10^{9} \mathrm{copies} / \mathrm{L}$, and the process examined in this study achieved that concentration. There were no clear differences in the concentration among the reactors. However, it is possible that the microbial activity in Reactors $\mathrm{B}$ and $\mathrm{C}$ was higher than the microbial activity in Reactor A.

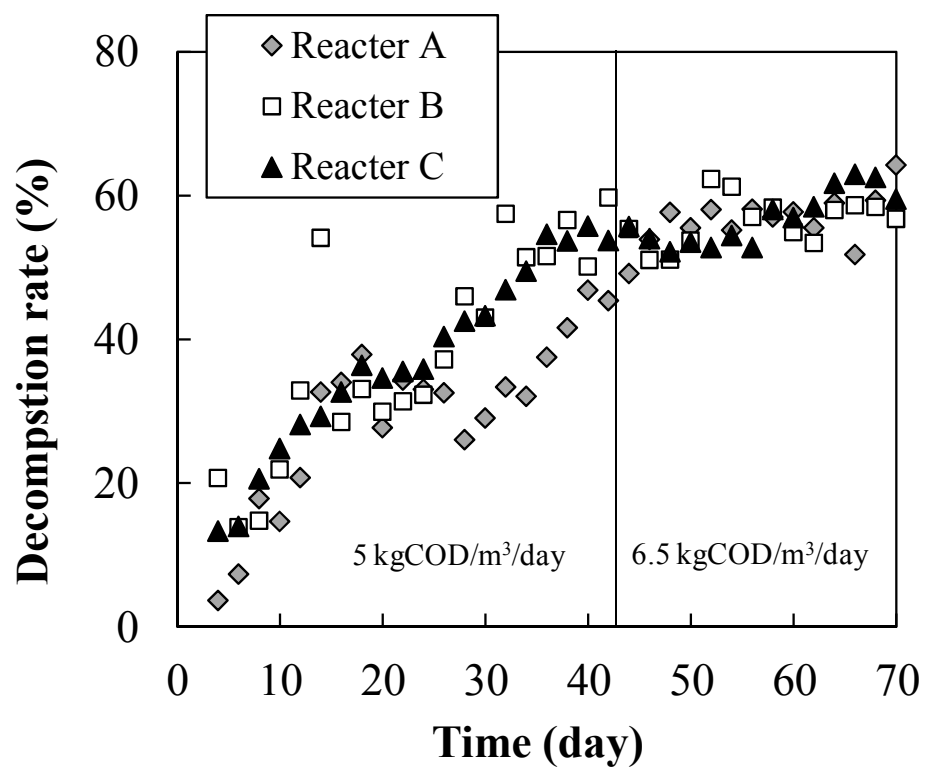

Fig. 10 - TS decomposition rate in each reactor. 

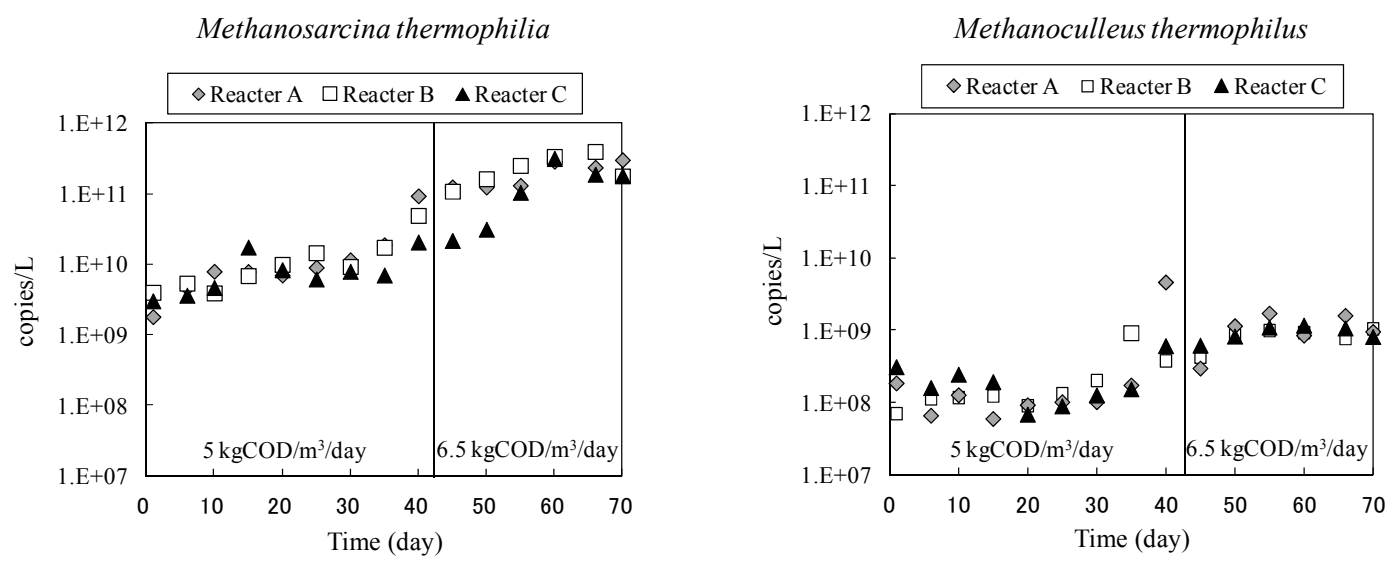

Fig. 11 - Mass of Methanosarcina thermophila and Methanoculleus thermophilus in each reactor.

\section{CONCLUSIONS}

Batch and continuous experiments were conducted to investigate the effects of a crush process on methane conversion efficiency in thermophilic anaerobic digestion with coffee grounds. The results are presented below.

1) The solubilization rates of the original coffee grounds (representative particle size: $>$ $1,000 \mu \mathrm{m})$ and the crushed grounds $(160 \mu \mathrm{m})$ were $5.00 \%$ and $10.2 \%$, respectively, at $55^{\circ} \mathrm{C}$ after $24 \mathrm{~h}$ in a batch experiment, which indicated that crushing enhanced solubilization.

2) Methane conversion efficiency of the crushed grounds (320 $\mu \mathrm{m}, 45.4 \%)$ was higher than the uncrushed grounds $(27.7 \%)$ in the thermophilic anaerobic digestion process $(120 \mathrm{~h})$ in a batch experiment. In addition, it is suggested that the enhancement of acetic acid generation contributed to conversion efficiency. Conversion efficiency decreased for crushed grounds $(160 \mu \mathrm{m})$ with a longer digestion period.

3) The continuous experiments showed that the average methane conversion efficiencies in the reactor with crushed coffee grounds $(320 \mu \mathrm{m})\left(41.1 \%\right.$ at $5 \mathrm{~kg} \mathrm{COD} / \mathrm{m}^{3} /$ day and $39.3 \%$ at $6.5 \mathrm{~kg} / \mathrm{m}^{3} /$ day) were higher than that of the original grounds $(33.4 \%$ and $32.4 \%$ ). The crushing process also improved TS decomposition, and sufficient concentrations of Methanosarcina thermophila was found in the reactors. Meanwhile, the process operation with $6.5 \mathrm{~kg} \mathrm{COD} / \mathrm{m}^{3} /$ day should be performed, carefully observing VFA accumulation.

Based on these results, anaerobic digestion using a crush process is effective, especially for coffee grounds with a representative particle size of $320 \mu \mathrm{m}$.

\section{REFERENCES}

All Japan Coffee Association (2012) Changes of import amount of coffee in Japan. http://ajca.or.jp/wp-content/uploads/2011/08/data01_2013_04.pdf (accessed April 22, 2013). (in Japanese) 
APHA-AWWA-WEF (2005) Standard methods for the examination of water and wastewater, 21st ed. American Public Health Association/American Water Works Association/Water Environment Federation, New York, USA.

Cheon J. H. (2006) Characterization and monitoring of microbial diversity in anaerobic bioreactor based on 16S rDNA. Doctoral dissertation, Department of Urban and Environmental Engineering, Kyoto University, Japan.

Cooney C. L. and Wise D. L. (1975) Thermophilic anaerobic digestion of solid waste for fuel gas production. Biotechnol. Bioeng., 17, 1119-1135.

Daoming S. and Forster C. F. (1993) An examination of the start-up of a thermophilic upflow sludge blanket reactor treating a synthetic coffee waste. Environ. Technol., 14, 965-972.

Dinsdale R. M., Hawkes F. R. and Hawkes D. L. (1996) The mesophilic and thermophilic anaerobic digestion of coffee waste containing coffee grounds. Water Res., 30, 371-377.

Hidaka T., Asahira T., Koshikawa H., Cheon J., Park Y. and Tsuno H. (2010) Effect of microbial composition on thermophilic acid fermentation. Enzyme Microb. Technol., 47, 127-133.

Ike M., Inoue D., Miyano T., Liu T. T., Sei K., Soda S. and Kadoshin S. (2010) Microbial population dynamics during startup of full-scale anaerobic digester treating industrial food waste in Kyoto eco-energy project. Bioresour. Technol., 101, 3952-3957.

Kamachi K., Tsukamoto Y., Onuma G. and Murakami M. (2010) Anaerobic digestion of coffee and tea waste with excess activated sludge. Environ. Sanit. Eng. Res., 24, 184-187.

Lane A. G. (1983) Anaerobic digestion of spent coffee grounds. Biomass, 3, 247-268.

Lee M., Hidaka T. and Tsuno H. (2008) Effect of temperature on performance and microbial diversity in hyperthermophilic digester system fed with kitchen garbage. Bioresour. Technol., 99, 6852-6860.

Noike T. (2009) Metan Hakkou (Methane fermentation). Gihodoshuppan, Tokyo, Japan, pp.85-86. (in Japanese)

Shigematsu T., Tang Y. Q. and Kida K. (2009) Microbial communities related to methane fermentation processes -monograph-. Seibutsu-kogaku Kaishi, 87, 570-596.

Tsubota J., Kadoshin S. and Tsuno H. (2008) Thermophilic digestion process without external dilution water for food factory waste that consists mainly of coffee grounds. J. Jpn. Soc. Waste Manage. Experts, 19, 51-60.

Watanabe K., Hidaka T., Nishimura F. and Tsuno H. (2012) Effect of alkaline agents and crush on combined hyperthermophilic solubilization and thermophilic methane fermentation of coffee grounds. Environ. Sanit. Eng. Res., 26, 77-80. (in Japanese) 